\title{
The Chemoselective Reduction of Isoxazoline $\gamma$-Lactams Through Iminium Aza-Diels-Alder Reactions: A Short-Cut Synthesis of Aminols as Valuable Intermediates towards Nucleoside Derivatives
}

\author{
Misal Giuseppe Memeo, Mariella Mella, and Paolo Quadrelli \\ Dipartimento di Chimica, Università degli Studi di Pavia, Viale Taramelli 12, 27100 Pavia, Italy \\ Correspondence should be addressed to Paolo Quadrelli, paolo.quadrelli@unipv.it
}

Received 27 December 2011; Accepted 16 January 2012

Academic Editors: S. De la Moya Cerero and G. B. Shul'pin

Copyright (C) 2012 Misal Giuseppe Memeo et al. This is an open access article distributed under the Creative Commons Attribution License, which permits unrestricted use, distribution, and reproduction in any medium, provided the original work is properly cited.

\begin{abstract}
Isoxazoline $\gamma$-lactams are prepared starting from the regioisomeric cycloadducts of benzonitrile oxide to the $N$-alkyl 2 azanorbornenes taking advantage of the efficient catalytic oxidation by $\mathrm{RuO}_{4}$. The reduction of the amide groups is easily conducted in the presence of $\mathrm{LiAlH}_{4}$ under mild conditions, which allowed for the chemoselective reduction of the amide moiety followed by ring opening to afford the desired conformationally locked isoxazoline-carbocyclic aminols, as valuable intermediates for nucleoside synthesis.
\end{abstract}

\section{Introduction}

Amino alcohols or aminols represent a class of relevant compounds, whose utility in organic synthesis is testified by their use as key building blocks and by the wide variety of biologically active compounds prepared using these stable intermediates [1-4]. The importance of vicinal aminols is also well recognized in asymmetric synthesis and many chiral auxiliaries and ligands contain these substructures $[5,6]$. The insertion of an amino and an hydroxy functionalities in a stereo ordinate way often determines the relevance and goodness of a synthetic method [7-13]. Recently, we have proposed a novel approach to useful aminols for the synthesis of carbocyclic nucleosides starting from an extremely convenient source, the 2-azanorborn-5-ene 1 (Scheme 1) [14], prepared by Grieco from the cycloaddition of cyclopentadiene with iminium salts generated in situ under Mannichlike conditions, in a mild and "green" aqueous aza-DielsAlder (ADA) reaction [15-26]. The first iminium salts as dienophiles in DA reactions were used by Böhme et al. for the synthesis of piperidinium salts [27] in 1963 but there is no doubt that the appearance of the first paper by Larsen and Grieco in 1985 determined the success in the use of unactivated iminium salts as dienophiles to prepare ADA cycloadducts in very good yields [18]. Despite the easy availability of these hetero-cycloadducts, no attempts have been made for their use in nucleosidic syntheses in general, or, in detail, in order to prepare conveniently the lactam derivatives as useful key intermediates towards aminols, the direct precursors of nucleoside structures. In order to apply this strategy, the aza-methylene bridge has to be modified, and the carbon C3 must be oxidized by appropriate procedures able to unmask the amide functionality [14]. The stable 2-azanorbornene of type 1 (Scheme 1, $\mathrm{R}=\mathrm{CH}_{2}$ $\mathrm{Ph}$ ) displays a moderate dipolarophilic activity towards benzonitrile oxide (BNO) and the 1,3-dipolar cycloaddition reaction affords the regioisomeric cycloadducts of type 2. Compared with norbornene, $N$-benzyl-2-azanorbornene still remains a highly reactive dipolarophile but less than the classical BNO trapping agent that is twice more reactive in apolar solvents and three times in polar or polarizable solvents [14]. 


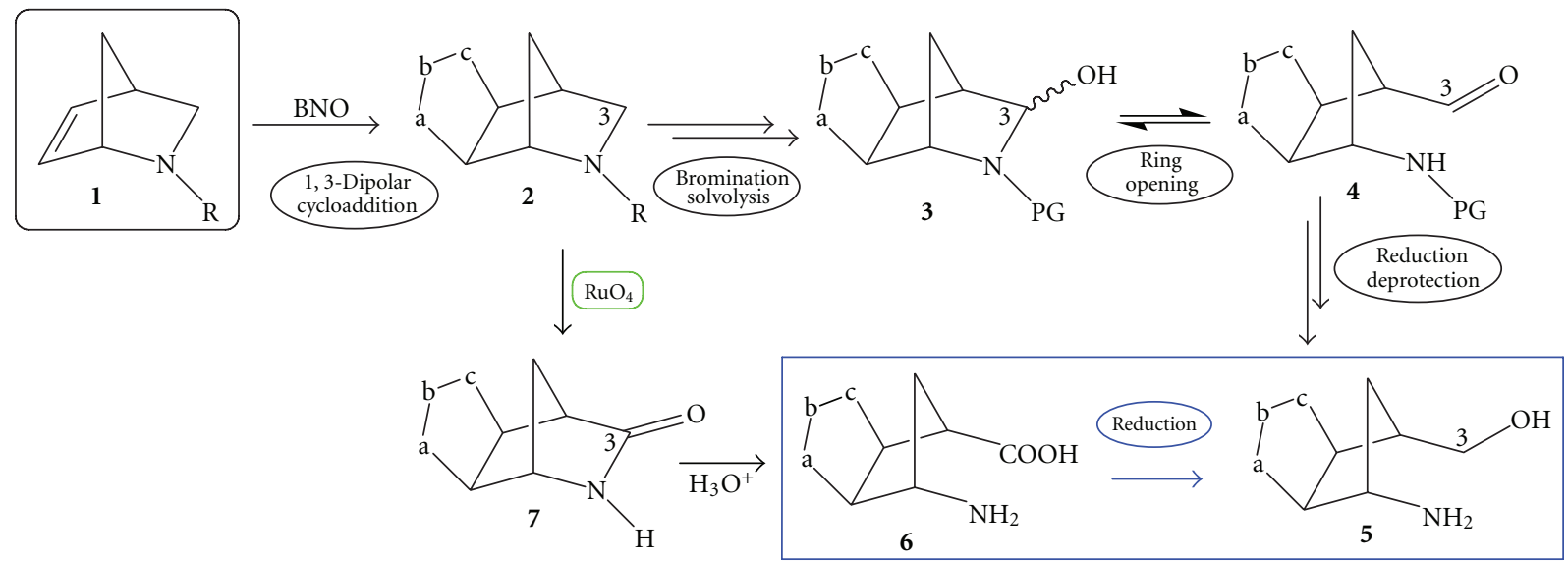

Scheme 1

Then, we transformed the cycloadducts 2 into more convenient derivatives, through the oxidation to the corresponding $N$-oxides and their conversion into $N$-acetyl derivatives via the mild Polonovski rearrangement $[28,29]$. Insertion of an acetyl as an amine protecting group (PG) on the 1,3dipolar cycloadducts and creation of an amide group nearby the methylene in position 3 allowed for the oxidation at the carbon atom C3 by means of NBS/AIBN bromination reaction, which afforded a complex mixture of products whose elaboration allowed for the isolation of the protected aldehyde 4 and ring opening. Reduction of the aldehyde group and deprotection afforded the target aminols 5. The overall protocol required from the beginning 8 steps to prepare the aminols 5, which were further converted into the desired adenine nucleoside derivatives [30, 31], which were submitted for biological tests against a variety of viruses.

In the search for a fast and convenient oxidation protocol we took advantage of the oxidative ability of $\mathrm{RuO}_{4}$, a strong oxidizing agent. Since its introduction into organic chemistry more than fifty years ago [32], $\mathrm{RuO}_{4}$-catalyzed reactions in a biphasic system were often considered to be sluggish or unselective [33]. Two recent papers by Petride and coworkers $[34,35]$ dealing with the $\mathrm{RuO}_{4}$-mediated oxidation of $\mathrm{N}$ benzylated tertiary amines (cyclic and acyclic) prompted us to test the $\mathrm{RuO}_{4}$ on our tricyclic isoxazolino-2azanorbornene derivatives of type 2 probing the regioselectivity of the oxidation process without replacing the benzyl group at the nitrogen atom or any other structure modification activating the adjacent methylene towards oxidation. This strategy was considered in view of the strong oxidative ability of $\mathrm{RuO}_{4}$. The protocol was successfully applied and allowed for inserting the carbonyl functionality in the position C3 of the azanorbornane moiety. The cycloadducts 2 were straight converted into the lactams 7 and from the latter the $\gamma$-amino acids 6 were prepared under hydrolytic conditions [36]. With these $\gamma$-amino acids 6 in hand we explored the reduction reactions for the planned conversion into the desired aminols of type 5 . In this paper we wish to report the mild chemoselective reduction of $\gamma$-lactams and $\gamma$-amino acids in the presence of $\mathrm{LiAlH}_{4}$, detailing the procedures to prepare a small library of stereodefined aminols from $N$-alkyl substituted 2azanorbornane derivatives. An overall and complete view of the synthetic connections among different starting materials and final products is given as a definitive picture of the new chemistry of 2-azanorbornene derivatives.

\section{Results}

2.1. The Reduction of the Regioisomeric Isoxazoline- $\gamma$-amino Acids. N-Benzyl-2-azanorborn-5-ene 1a was prepared by addition of freshly distilled cyclopentadiene to an aqueous solution of benzylamine hydrochloride and 37\% aqueous formaldehyde in an ADA reaction according to the wellknown procedure $[15,16]$. The 1,3-dipolar cycloaddition of BNO with 1a was performed by generating the 1,3dipole with the in situ procedure [37], affording the two regioisomeric cycloadducts $2 \mathbf{a A}$ and $\mathbf{2 a B}$ in $49 \%$ and $43 \%$ yields, respectively (Scheme 2) [14].

The regioisomeric cycloadducts $2 \mathrm{aA}$ and $2 \mathrm{aB}$ were oxidized by using the catalytic system $\mathrm{RuO}_{2} / \mathrm{NaIO}_{4}$ with the $\mathrm{H}_{2} \mathrm{O} / \mathrm{AcO} \mathrm{Ot}$ biphasic conditions $[38,39]$. The protocol needs only a catalytic amount of the expensive $\mathrm{RuO}_{2} \cdot \mathrm{H}_{2} \mathrm{O}(10-$ $20 \%$ mol.) in the presence of 2.5 equivalents (with respect to the substrate to be oxidized) of sodium periodate as oxidant in order to regenerate the oxidizing species $\mathrm{RuO}_{4}$ at the highest oxidation state after the end of the catalytic cycle [4042]. Typically, $\mathrm{RuO}_{2} \cdot \mathrm{H}_{2} \mathrm{O}$ is added to a solution of $\mathrm{NaIO}_{4}$ in water in inert atmosphere and left under stirring for 30 minutes. The formation of the $\mathrm{RuO}_{4}$ species at the highest oxidation state becomes clear because of the bright yellow colour solution.

At this point, ethyl acetate solutions of the substrate are added in one portion. The reaction mixture instantly turns an opaque-black colour. The cycloadducts $2 \mathbf{a A}, \mathbf{B}$ disappear almost completely in the reaction time (TLC monitoring required to fix the end of the reaction) and the formation of three new products for each regioisomer was observed [36]. They are all amide derivatives where the oxidation occurred both on the Endocyclic and Exocyclic active methylenes adjacent to the nitrogen atom. When the oxidation on the 


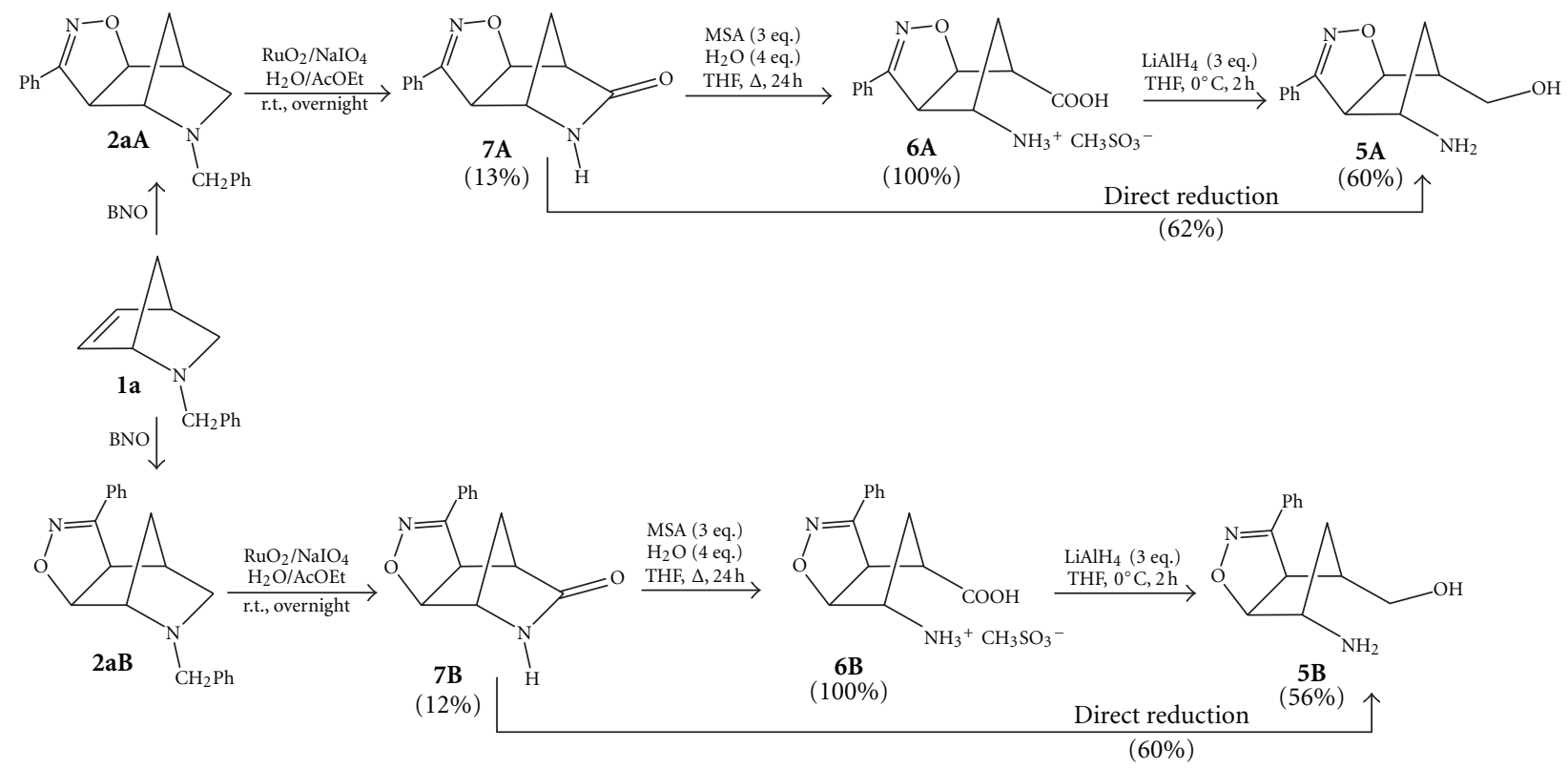

Scheme 2

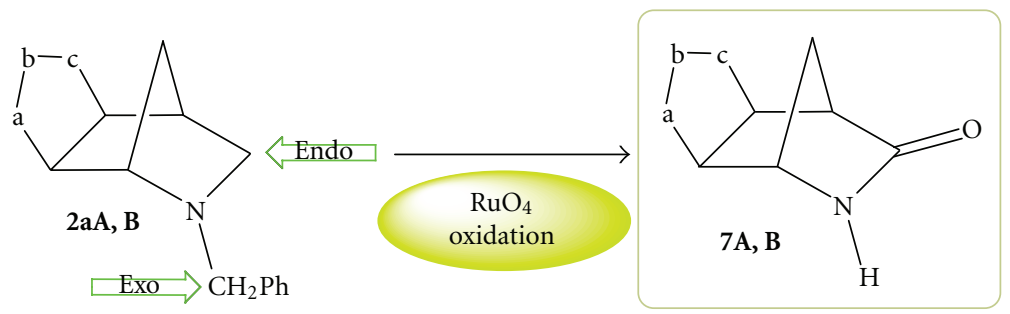

Scheme 3

Endocyclic methylene occurred, the process is accompanied by detachment of the benzyl group (vide infra); these are our target regioisomeric lactams of type 7A,B and are formed in $13 \%$ and $12 \%$ yields, respectively (Scheme 3 ). These modest yields can be improved by $10 \%$ by adding the ethyl acetate solutions of the substrates to be oxidized portionwise.

The transformation of the lactams 7A,B into the desired $\gamma$-amino acids $\mathbf{6 A , B}$ was secured by the easy and quantitative hydrolysis in the presence of 3 equivalents of methanesulfonic acid (MSA) and 4 equivalents of water in THF at reflux for $24 \mathrm{~h}$ [43]. Insoluble methanesulfonic acid salts of the regioisomeric amino acids $6 \mathbf{A}, \mathbf{B}$ separate from the organic solution and the products are easily isolated in quantitative yields by simple filtration (Scheme 2 ).

The reduction of the $\gamma$-amino acids $\mathbf{6 A , B}$ was then investigated to find the best and mildest reaction condition to prepare the desired aminols $\mathbf{5 A}, \mathbf{B}$, where the isoxazoline ring must be preserved during the reduction process. The use of classical borane-tetrahydrofuran $\left(\mathrm{BH}_{3} \cdot \mathrm{THF}\right)$ as an electrophilic agent to reduce the carboxylic acid functionality was found weakly enough to save the isoxazoline moiety but did not give the expected results [44], leaving unaltered the starting materials. An alternative and mild method to reduce the $\mathrm{COOH}$ group in the presence of other functionalities takes advantage of the coupling of $\mathrm{NaBH}_{4}$ with $\mathrm{I}_{2}$ but, again, the starting amino acids were recovered mostly unchanged [45]. We decided to test $\mathrm{LiAlH}_{4}$ to perform this reduction, in spite of the known tendency of this strong reductive agent to reduce and open isoxazole and isoxazoline rings [46]. For this reason we performed several tests on small amounts (analytical scale) of the acids $\mathbf{6 A , B}$ before scaling up for synthetic purposes. We also applied different experimental conditions, finding at the end the mildest and promising, possible. Solutions in anhydrous THF of the regioisomeric $\gamma$ amino acids 6A,B were treated with 3 equivalents of $\mathrm{LiAlH}_{4}$ added portionwise at $0^{\circ} \mathrm{C}$ under stirring and the reactions were monitored by TLC until disappearance of the starting compounds. In 1-2 hours the reactions were completed and excess $\mathrm{LiAlH}_{4}$ was rapidly destroyed by adding ethyl acetate at $0^{\circ} \mathrm{C}$ up to room temperature. The organic phases were then washed twice with brine and dried over anhydrous $\mathrm{Na}_{2} \mathrm{SO}_{4}$. Upon evaporation of the solvent, the residues furnished successfully the desired aminols 5A,B in 60\% and 56\% yields, respectively, which were purified by MPLC (Scheme 2 ). The products were characterized and found identical to authentic samples of the aminols prepared according to the previously reported synthetic procedure [14]. 

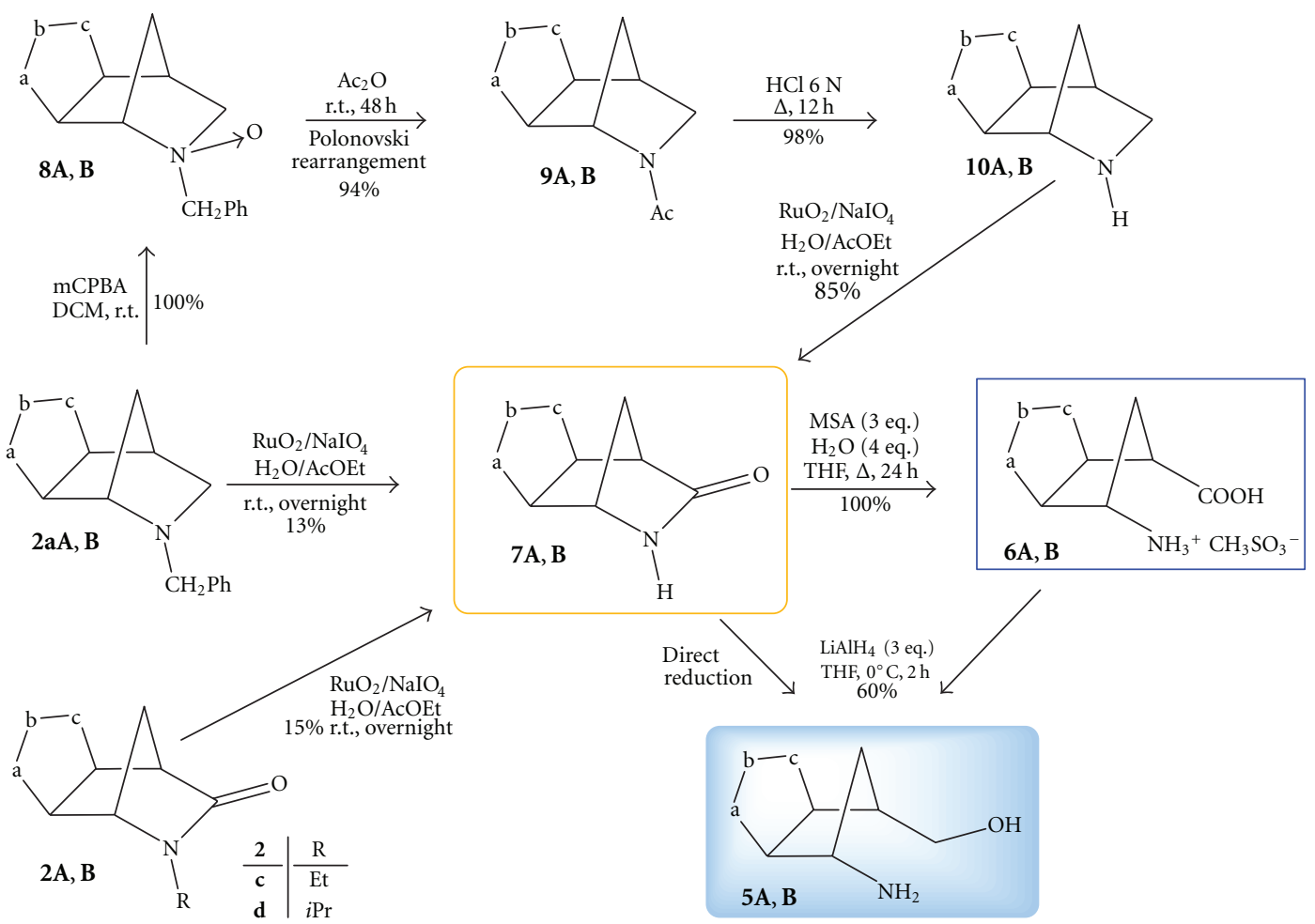

Scheme 4
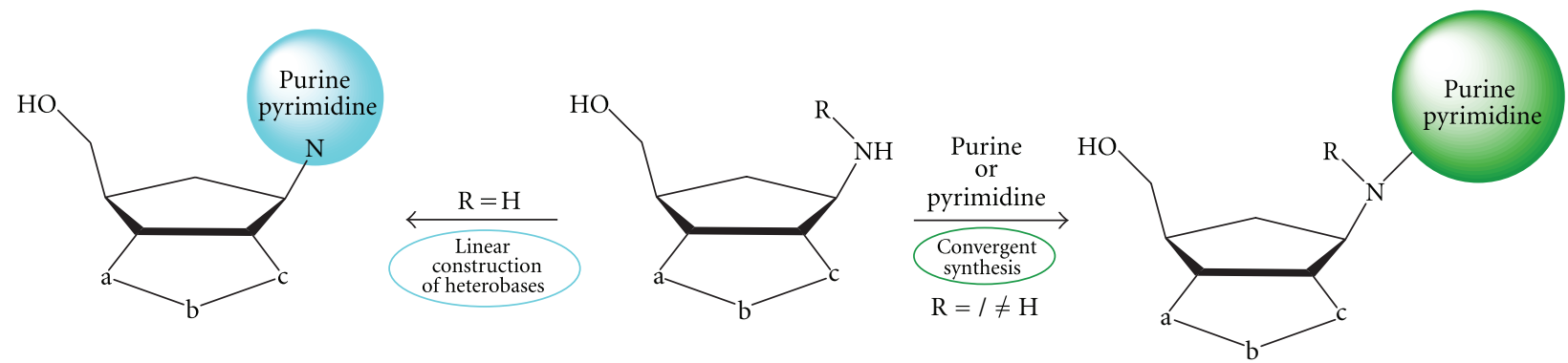

Scheme 5

2.2. Direct Reduction of $\gamma$-Lactams to Aminols. The successful and chemoselective reduction of the $\gamma$-amino acids $\mathbf{6 A , B}$ prompted us to explore the feasibility of the direct reduction of lactams 7A,B bypassing the intermediate step to amino acids by applying the same or a slightly modified protocol. The regioisomeric lactams 7A,B were dissolved in anhydrous THF and 3 equivalents of $\mathrm{LiAlH}_{4}$ were added portionwise under stirring at $0^{\circ} \mathrm{C}$. Upon monitoring by TLC, the reactions reached completion in $2 \mathrm{~h}$ affording, after a rapid quenching at $0^{\circ} \mathrm{C}$ of excess $\mathrm{LiAlH}_{4}$ with ethyl acetate, the desired aminols 5A,B in $62 \%$ and $60 \%$ yields, respectively, (Scheme 2). However, the great oxidative power, $\mathrm{LiAlH}_{4}$ can be used successfully under mild operative conditions to selectively reduce also the amide group located in the strained structure of the tricyclic $\gamma$-lactams 7A,B. For these reasons, as the nucleophilic hydride attacks the carbonyl group, the amide $\mathrm{N}-\mathrm{C}=\mathrm{O}$ single bond weakens and ring opening is favoured by the relief of strain due to the collapse of the tricyclic heterocycle into a bicyclic structure [47-50].

These results somewhat require to summarize the various pathways available to reach the target aminols from different sources. The synthetic connections among the 1,3-dipolar cycloadducts to the 2-azanorbornene derivatives, intermediates, and final products are reported in Scheme 4. The key lactams 7A,B are obtainable from direct $\mathrm{RuO}_{4}$-mediated oxidation of $N$-benzyl cycloadducts $2 \mathbf{a A}, \mathbf{B}$ [36].

Alternatively, a more efficient and expedite route to the lactams 7A,B takes advantage of the already applied protocol [14] through the oxidation of the regioisomeric cycloadducts $2 \mathbf{a A}, \mathbf{B}$ to the corresponding $N$-oxides $\mathbf{8 A}, \mathbf{B}$, followed by the Polonovski rearrangement to prepare the $N$ acetyl derivatives 9A,B in quantitative yields. A facile hydrolysis with boiling $\mathrm{HCl} 6 \mathrm{~N}$ for $12 \mathrm{~h}$ afforded quantitatively the deprotected cycloadducts 10A,B (Scheme 4) and, by 
applying the oxidation protocol with $\mathrm{RuO}_{2} / \mathrm{NaIO}_{4}$, the latter were converted in good yields into the lactams $7 \mathrm{~A}, \mathbf{B}$. A third approach to lactams $\mathbf{7 A , B}$ has been recently accounted and some regioisomeric $N$-alkyl derivatives of type $2 \mathbf{c}, \mathbf{d}$, where a methyne or a methylene group is attached to the nitrogen atom, can be oxidized under the usual protocol into the lactams 7A,B in modest yields [45]. Having the lactams 7A,B in hand, the desired final targets, $\gamma$-amino acids $6 \mathrm{~A}, \mathrm{~B}$ and/or aminol $\mathbf{5 A}, \mathbf{B}$, can be pursued through the easy application of the reported methods. The synthetic relevance of these aminols is linked to their use in the linear construction of purine and pyrimidine heterobases, that is, the synthesis of carbocyclic nucleosides with potential antiviral activity $[14,30,31]$.

2.3. N-Alkyl Aminols. The $\mathrm{RuO}_{4}$-catalyzed oxidation reactions of some $\mathrm{N}$-alkyl substituted isoxazolino-2-azanorbornane cycloadducts, obtained from the 1,3-dipolar cycloaddition reactions with benzonitrile oxide (BNO) to the corresponding $N$-alkyl substituted 2-azanorborn-5-enes, afforded a short-cut entry to valuable bridged $\gamma$-lactams, potentially analogues of classical $\beta$-lactam antibiotics [51]. In order to have further insights on scope and limitations of the mild and chemoselective reductive protocol based on the use of $\mathrm{LiAlH}_{4}$, we have furtherly investigated the reduction of these novel lactams with the aim to prepare a small library of $\mathrm{N}$-alkyl substituted aminols as valuable intermediates for the convergent synthesis of novel nucleoside analogues, where the nucleophilic nitrogen atom is used to link either commercially available or properly synthesized purine and pyrimidine bases bearing an appropriate leaving group. The strategy is reported in Scheme 5 and is complementary as well as straightforward to the desired nucleoside analogues with respect to the linear construction of purine and pyrimidine heterobases, that requires more steps to the targets [14].

The regioisomeric cycloadducts $2 \mathrm{~A}, \mathbf{B}(\mathbf{b}-\mathbf{e})$ were oxidized by using the catalytic system $\mathrm{RuO}_{2} / \mathrm{NaIO}_{4}$ with the $\mathrm{H}_{2} \mathrm{O} / \mathrm{AcOEt}$ biphasic conditions $[38,39]$. The lactams 7A,B (b-e) were isolated in moderate yields as part of a complex mixture of oxidized compounds (Scheme 6). The direct reduction reactions were conducted by dissolving the regioisomeric lactams $\mathbf{7 A , B}$ in anhydrous THF and 3 equivalents of $\mathrm{LiAlH}_{4}$ were added portionwise under stirring at $0^{\circ} \mathrm{C}$. Upon monitoring by TLC, the reactions reached completion in 1-2 $\mathrm{h}$ affording, after the usual workup, the desired aminols 11A,B (b-e) from 53\% to $68 \%$ yields.

The structures of the newly prepared $N$-alkyl aminols 11 rely upon their analytical and spectroscopic data. The comparison of the spectroscopic data of the aminols 11 with those of the starting lactams 7A,B allowed for a firm assignment of the structures reported. The regioisomeric aminols 11bA,B were clearly identified since in the ${ }^{1} \mathrm{H}$ NMR spectra a new $A B$ system appears at $\delta 3.81$ for both regioisomers corresponding to the hydroxy methylene group $\left(\mathrm{CH}_{2}-\mathrm{OH}\right)$; moreover in the ${ }^{13} \mathrm{C}$ NMR spectra the signals relative to the amide carbonyl groups at $\delta 173-176$ are now missing.
The ${ }^{1} \mathrm{H}$ NMR spectra of the $N$-Et substituted aminols 11cA,B showed the hydroxy methylene groups as $A B$ systems at $\delta 3.61$ and 3.83 for compound $11 \mathrm{cA}$ and at $\delta 3.59$ and 3.76 for compound $11 \mathrm{cB}$; the relative ${ }^{13} \mathrm{C}$ NMR spectra showed the absence of the amide carbonyl groups at $\delta 173-$ 175. Similarly, the ${ }^{1} \mathrm{H}$ NMR spectra of the $N$-iPr substituted aminols 11dA,B showed the hydroxy methylene groups as $\mathrm{AB}$ systems at $\delta 3.62$ and 3.82 for compound $11 \mathrm{dA}$ and at $\delta 3.58$ and 3.81 for compound $11 \mathrm{~dB}$; the relative ${ }^{13} \mathrm{C}$ NMR spectra showed the absence of the amide carbonyl groups at $\delta 172$ 174. Finally, the ${ }^{1} \mathrm{H}$ NMR spectra of the $N-t B u$ substituted aminols 11eA,B showed the hydroxy methylene groups as $\mathrm{AB}$ systems at $\delta 3.66$ for compound $11 \mathrm{eA}$ and at $\delta 3.64$ and 3.78 for compound $11 \mathrm{eB}$; the relative ${ }^{13} \mathrm{C}$ NMR spectra showed the absence of the amide carbonyl groups at $\delta$ 173-175.

All the structures of the aminols $11 \mathrm{~A}, \mathrm{~B}$ reported are also characterized by strong IR bands of the $\mathrm{OH}$ group between $3300-3375 \mathrm{~cm}^{-1}$, which cover the NH bands of the amine group.

\section{Discussion}

The $\mathrm{RuO}_{4}$-catalyzed oxidation protocol has been applied to the isoxazolino-2-azanorbornane derivatives in the search of an expedite and selective oxidation towards lactam derivatives as precursors of valuable aminols. The latter are in fact the ideal starting materials for nucleosides and natural products syntheses. It is worthwhile to remember that Ruthenium tetroxide was firstly employed in strong and quite unselective oxidations [32]. In general, the reactions required a biphasic system of organic solvent and water to be performed allowing $\mathrm{RuO}_{4}$ to display its complete oxidizing power [33]. Oxidation of $\mathrm{C}-\mathrm{H}$ bonds represents the most intriguing property of the ruthenium tetroxide as oxidant in 1,2-dehydrogenation of alcohols and amines as well as in 1,1-dehydrogenation of saturated hydrocarbons, a quite uncommon process but extremely useful from the synthetic point of view, allowing for the introduction of oxidated functionalities on activated methylenes [38, 39]. The mechanism proposed by Bakke et al. [52-54] and widely recognised in its validity is shown in the inset of Scheme 7. The oxidation process takes place in two separate steps: (1) oxidative addition of $\mathrm{RuO}_{4}$ to the $\mathrm{C}-\mathrm{H}$ bond (A) through a concerted transition state (TS) yielding the metal alcoholate with a reduced $\mathrm{Ru}(\mathrm{VI})(\mathrm{B})$; (2) fragmentation of the metal alcoholate affording the carbonyl compound while $\mathrm{Ru}(\mathrm{VI})$ is reduced at $\mathrm{Ru}$ (IV) (C) which must be reoxidized to $\mathrm{Ru}$ (VIII) by the sodium periodate to restart the catalytic cycle $[33,38$, $39,55]$. A valuable alternative mechanism is the hydrogen abstraction from the $\mathrm{C}-\mathrm{H}$ bond by the $\mathrm{Ru}=\mathrm{O}$ fragment to afford, after ligand migration, the metal alcoholate (B) that undergoes the final oxidative step [56].

The regioselectivity of the oxidation of $\mathrm{N}$-benzylated tertiary amines has already been presented by Petride and coworkers $[34,35]$. In the case of the tricyclic 2azanorbornane derivatives at hand, two different methylenes (exocyclic and endocyclic) are activated by the same nitrogen 


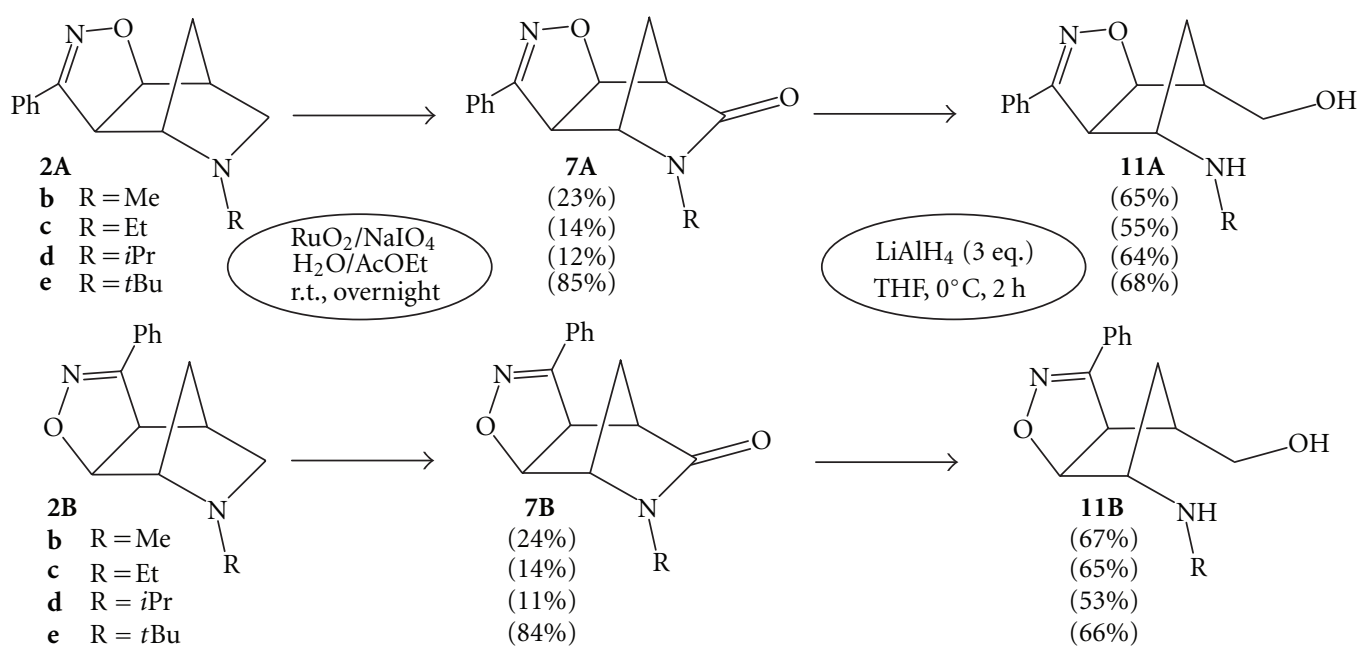

SCheme 6
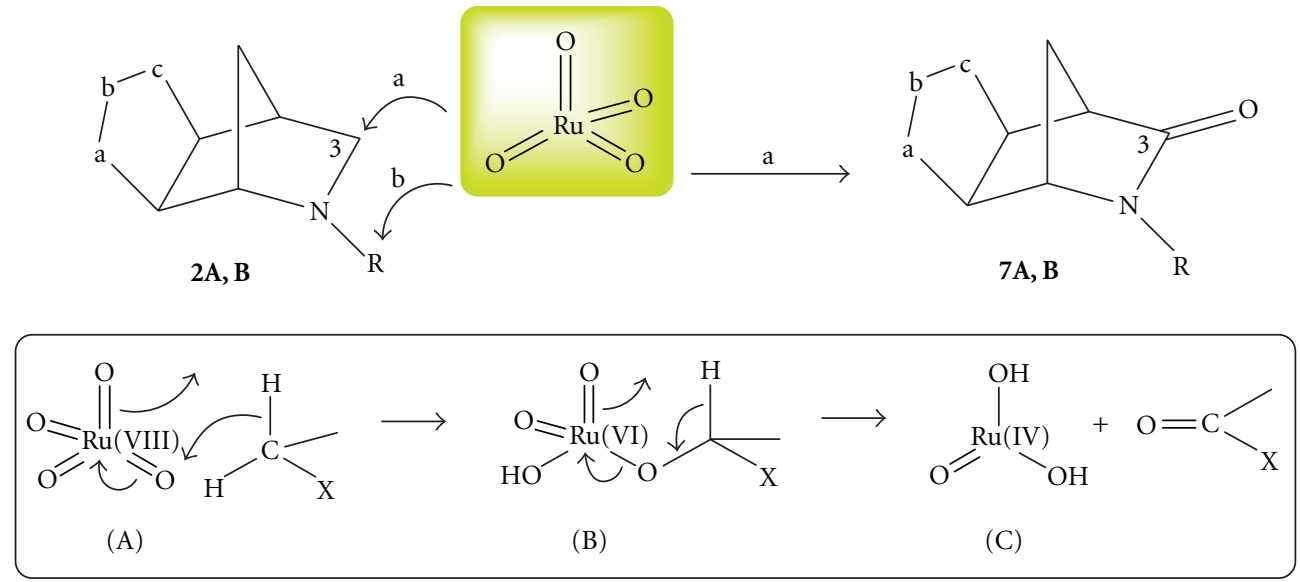

SCHEME 7

atom and the oxidation reaction proceeds with poor regioselection and both the methylenes are involved affording two different amides $[36,55]$. However, when cycloadducts 2A,B undergo oxidation by $\mathrm{RuO}_{4}$ on the endocyclic (path a) methylenes, the amides 7A,B are easily obtained (Scheme 7) from moderate to fair yields.

These tricyclic amides display the intriguing competition between the amide moiety and the isoxazoline ring towards reduction in the presence of a potential variety of reductive agents. The method has been validated using $\mathrm{LiAlH}_{4}$ in THF as solvent at $0^{\circ} \mathrm{C}$ until disappearance of the starting materials in accordance with the literature findings concerning the reduction of amides under special experimental conditions [57]. The weak N-O bond of isoxazoline rings can be cleaved reductively by two principal methods: catalytic hydrogenation or treatment with $\mathrm{LiAlH}_{4}$ [46]. Since this ring opening is a key step in the construction of complex molecules the experimental conditions of the two reactions have been investigated thoroughly by different authors. Reductions with $\mathrm{LiAlH}_{4}$ are carried out predominantly in ethers as solvent $\left(\mathrm{Et}_{2} \mathrm{O}\right.$, THF, Dioxane) heating the solutions at reflux for several hours allowing for the preparation of the required aminol structures [46].

In the cases at hand, $\mathrm{LiAlH}_{4}$ is used under milder and controlled conditions at $0^{\circ} \mathrm{C}$ in THF calibrating the reaction time on the consume of the starting amides $7 \mathbf{A}, \mathbf{B}$ (Scheme 8), monitoring constantly by TLC the evolution of the reactions. In order to reach the complete transformation of the amides into the aminols, we used 3 equivalents of $\mathrm{LiAlH}_{4}$ since the reactions proceed through more than a single step (reduction, ring opening) to produce the desired aminols $\mathbf{5 A}, \mathbf{B}$ and $\mathbf{1 1 A}, \mathbf{B}$, depending on the presence of an alkyl substituent on the amino group. As a consequence, the reduction conducted on the isolated amino acids $\mathbf{6 A , B}$ affords the target compounds. The protocol can be nicely applied to single regioisomers of amides $\mathbf{7 A , B}$ or onto the regioisomeric mixtures of the same compounds, separating the regioisomeric aminols 5A,B and 11A,B during the final purification through column chromatography. The results in terms of yields are quite good. Nevertheless, in some 


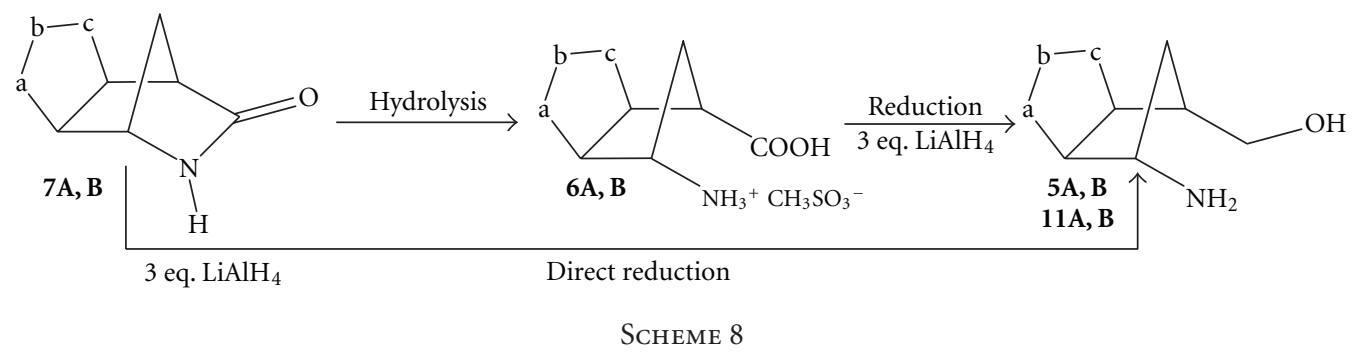

cases, in repeated experiments performed to demonstrate the reproducibility of the method, few amounts of the 2alkyl azanorbornane cycloadducts $(6-11 \%)$ were identified and isolated as a result of the amide reduction without cleavage [58-60]; that is, the chemoselective reduction of the amide group in the presence of an isoxazoline ring remains a delicate process but feasible if properly tuned up according to the structures at hand.

\section{Conclusions}

In conclusion, we have developed a short synthetic procedure for the synthesis of valuable aminols conformationally constrained because of the fused heterocyclic ring to the cyclopentane moiety with some alkyl substituents on the amino group. The key intermediates are the lactams 7A,B whose preparation can be performed starting from the regioisomeric cycloadducts to the $N$-alkyl 2-azanorbornene 2A,B taking advantage of the efficient catalytic oxidation by $\mathrm{RuO}_{4}[36,51]$. The chemoselective reduction of the amide groups is easily conducted in the presence of excess $\mathrm{LiAlH}_{4}$ under mild and controlled conditions. Concomitant ring opening afforded the desired isoxazoline-carbocyclic aminols $\mathbf{1 1 A} \mathbf{B}$, as key intermediates for our studies in nucleoside syntheses. Samples of compounds 5A,B and 11A,B will be used in a short-cut and linear synthesis of classical nucleosides according to the well-established protocols [14, 30,31 ] as well as unusual nucleoside analogues through the convergent planned methodology.

\section{Experimental Section}

5.1. General. All melting points are uncorrected. Elemental analyses were done on a C. Erba 1106 elemental analyzer available in our department. IR spectra (nujol mulls or neat in case of oils) were recorded on an FT-IR PerkinElmer RX-1. ${ }^{1} \mathrm{H}$ - and ${ }^{13} \mathrm{C}-\mathrm{NMR}$ spectra were recorded on a Bruker AVANCE 300 in the specified deuterated solvents. Chemical shifts are expressed in $\operatorname{ppm}(\delta)$ from internal tetramethylsilane.

Column chromatography and tlc: silica gel $60(0.063-$ $0.200 \mathrm{~mm}$ ) (Merck); eluant chloroform and chloroform/ methanol 9:1. MPLC: Biotage FMP apparatus equipped with KP-SIL columns, eluant chloroform and chloroform/methanol 9:1. The identification of samples from different experiments was secured by mixed mps and superimposable IR spectra.
5.2. Materials. Lactams $7 \mathbf{A}, \mathbf{B}(\mathbf{a}-\mathbf{e})$ and the amino acids $\mathbf{6 A}, \mathbf{B}$ were prepared according to previously reported procedures $[36,51]$. Ruthenium (IV) oxide hydrate $\left(\mathrm{RuO}_{2} \cdot \mathrm{H}_{2} \mathrm{O}\right)$, sodium periodate, and $\mathrm{LiAlH}_{4}$ are from Sigma-Aldrich. All other reagents and solvents were purchased and used without any further purification. Anhydrous THF was distilled over metallic sodium.

5.3. General Procedure for Reduction Reactions with $\mathrm{LiAlH}_{4}$. Solutions in anhydrous THF of the regioisomeric $\gamma$-amino acids 6 A,B or of the regioisomeric lactams 7A,B were treated with 3 equivalents of $\mathrm{LiAlH}_{4}$ added portionwise at $0^{\circ} \mathrm{C}$ under stirring and the reactions were monitored by TLC until disappearance of the starting compounds. In a couple of hours the reactions were completed and excess $\mathrm{LiAlH}_{4}$ was rapidly destroyed by adding ethyl acetate from $0^{\circ} \mathrm{C}$ to room temperature. The organic phases were then washed twice with brine and dried over anhydrous $\mathrm{Na}_{2} \mathrm{SO}_{4}$. Upon evaporation of the solvent, the residues furnished the desired aminols 11A,B, which were purified by MPLC. Aminols 5A,B were found identical to previously prepared samples [14]. New compounds were fully characterized as follows.

11Ab. (65\%), pale yellow oil. IR: $\nu_{\max } 3370,1569 \mathrm{~cm}^{-1}$. $R_{f}$ (chloroform/methanol 9:1) $0.26 .{ }^{1} \mathrm{H}-\mathrm{NMR}(300 \mathrm{MHz}$, $\left.\mathrm{CDCl}_{3}\right): \delta_{\mathrm{H}} 2.01(1 \mathrm{H}, \mathrm{d}, J 15 \mathrm{~Hz}, \mathrm{H}-\mathrm{CH}) ; 2.21(1 \mathrm{H}, \mathrm{m}$, $\mathrm{HC}-\mathrm{H}) ; 2.70(1 \mathrm{H}, \mathrm{m}, \mathrm{CH}) ; 2.80\left(3 \mathrm{H}, \mathrm{d}, J 5 \mathrm{~Hz}, \mathrm{CH}_{3}\right) ; 3.81$ $\left(2 \mathrm{H}, \mathrm{d}, J 6 \mathrm{~Hz}, \mathrm{CH}_{2}-\mathrm{OH}\right) ; 4.51\left(1 \mathrm{H}, \mathrm{d}, J 9 \mathrm{~Hz}, \mathrm{H} 4_{\text {isox }}\right) ; 4.72$ $(1 \mathrm{H}, \mathrm{d}, J 6 \mathrm{~Hz}, \mathrm{CH}-\mathrm{N}) ; 5.26\left(1 \mathrm{H}, \mathrm{d}, J 9 \mathrm{~Hz}, \mathrm{H} 5_{\text {isox }}\right) ; 7.54$ (3H, m, arom.); 8.06 (2H, m, arom.). ${ }^{13} \mathrm{C}-\mathrm{NMR}(75 \mathrm{MHz}$, $\left.\mathrm{CDCl}_{3}\right) \delta_{\mathrm{C}} 30.7\left(\mathrm{CH}_{2}\right), 32.9(\mathrm{CH}), 49.5(\mathrm{CH}-\mathrm{NH}), 58.8$ $\left(\mathrm{CH}_{3}-\mathrm{NH}\right), 64.5\left(\mathrm{CH}_{2}-\mathrm{OH}\right), 86.7(\mathrm{CH}-\mathrm{C}=\mathrm{N}), 89.6(\mathrm{CH}-$ O), 127.4, 128.7, 129.7 and 130.8 (arom.), $156.7(\mathrm{C}=\mathrm{N})$. Anal. Calcd. for $\mathrm{C}_{14} \mathrm{H}_{18} \mathrm{~N}_{2} \mathrm{O}_{2}(\mathrm{MW}=246.30)$ : C, 68.27; $\mathrm{H}$, 7.37; N, 11.37. Found: C, 68.30; H, 7.40; N, 11.30.

11Bb. (67\%), yellowish oil. IR: $v_{\max } 3375,1614 \mathrm{~cm}^{-1}$. $R_{f}$ (chloroform/methanol 9:1) $0.23 .{ }^{1} \mathrm{H}-\mathrm{NMR}(300 \mathrm{MHz}$, $\left.\mathrm{CDCl}_{3}\right): \delta_{\mathrm{H}} 1.30\left(2 \mathrm{H}, \mathrm{m}, \mathrm{CH}_{2}\right) ; 2.51(1 \mathrm{H}, \mathrm{m}, \mathrm{CH}) ; 2.76(3 \mathrm{H}$, d, J $\left.5 \mathrm{~Hz}, \mathrm{CH}_{3}\right) ; 3.81\left(2 \mathrm{H}\right.$, dd, J 6, $\left.2 \mathrm{~Hz}, \mathrm{CH}_{2}-\mathrm{OH}\right) ; 4.26(1 \mathrm{H}$, dd, J 9, $\left.2 \mathrm{~Hz}, \mathrm{H} 4_{\text {isox }}\right) ; 4.77(1 \mathrm{H}, \mathrm{d}, J 3 \mathrm{~Hz}, \mathrm{CH}-\mathrm{N}) ; 5.11(1 \mathrm{H}$, b, NH); 5.36 (1H, d, J $\left.9 \mathrm{~Hz}, \mathrm{H} 5_{\text {isox }}\right) ; 7.46$ (3H, m, arom. $) ; 7.88$ $\left(2 \mathrm{H}, \mathrm{m}\right.$, arom.). ${ }^{13} \mathrm{C}-\mathrm{NMR}\left(75 \mathrm{MHz}, \mathrm{CDCl}_{3}\right) \delta_{\mathrm{C}} 30.7\left(\mathrm{CH}_{2}\right)$, $32.2(\mathrm{CH}), 47.1(\mathrm{CH}-\mathrm{NH}), 54.0\left(\mathrm{CH}_{3}-\mathrm{NH}\right), 66.4\left(\mathrm{CH}_{2}-\right.$ $\mathrm{OH}), 88.0(\mathrm{CH}-\mathrm{C}=\mathrm{N}), 90.3(\mathrm{CH}-\mathrm{O}), 127.3,128.7,129.8$ and 130.6 (arom.), $158.8(\mathrm{C}=\mathrm{N})$. Anal. Calcd. for $\mathrm{C}_{14} \mathrm{H}_{18} \mathrm{~N}_{2} \mathrm{O}_{2}$ 
$(\mathrm{MW}=246.30): \mathrm{C}, 68.27 ; \mathrm{H}, 7.37 ; \mathrm{N}, 11.37$. Found: $\mathrm{C}, 68.22$; $\mathrm{H}, 7.40 ; \mathrm{N}, 11.32$.

11Ac. (55\%), brown oil. IR: $\nu_{\max } 3301,1620 \mathrm{~cm}^{-1} \cdot R_{f}$ (chloroform/methanol 9:1) 0.27. ${ }^{1} \mathrm{H}-\mathrm{NMR}\left(300 \mathrm{MHz}, \mathrm{CDCl}_{3}\right)$ : $\delta_{\mathrm{H}} 1.19\left(3 \mathrm{H}, \mathrm{t}, J 7 \mathrm{~Hz}, \mathrm{CH}_{3}\right) ; 1.63(1 \mathrm{H}, \mathrm{d}, \mathrm{HC}-\mathrm{H}) ; 2.16(1 \mathrm{H}$, $\mathrm{m}, \mathrm{H}-\mathrm{CH}) ; 2.74\left(2 \mathrm{H}, \mathrm{q}, J 7 \mathrm{~Hz}, \mathrm{CH}_{2}\right) ; 3.34(1 \mathrm{H}, \mathrm{d}, J 6 \mathrm{~Hz}$, $\left.\mathrm{CH}-\mathrm{CH}_{2}-\mathrm{OH}\right) ; 3.61$ and 3.83 (2H, AB syst., $\left.\mathrm{CH}_{2}-\mathrm{OH}\right) ; 3.70$ $(1 \mathrm{H}, \mathrm{t}, J 6 \mathrm{~Hz}, \mathrm{CH}-\mathrm{N}) ; 3.90\left(1 \mathrm{H}, \mathrm{d}, J 9 \mathrm{~Hz}, \mathrm{H} 4_{\text {isox }}\right) ; 5.28(1 \mathrm{H}$, d, J $\left.9 \mathrm{~Hz}, \mathrm{H} 5_{\text {isox }}\right) ; 7.44$ (3H, m, arom.); 7.72 (2H, m, arom.). ${ }^{13} \mathrm{C}-\mathrm{NMR}\left(75 \mathrm{MHz}, \mathrm{CDCl}_{3}\right) \delta_{\mathrm{C}} 14.8\left(\mathrm{CH}_{3}\right), 35.5\left(\mathrm{CH}_{2}\right), 41.5$ (CH), $49.3(\mathrm{CH}-\mathrm{NH}), 59.8\left(\mathrm{CH}_{2}-\mathrm{NH}\right), 62.6\left(\mathrm{CH}_{2}-\mathrm{OH}\right)$, $64.0(\mathrm{CH}-\mathrm{C}=\mathrm{N}), 90.7(\mathrm{CH}-\mathrm{O}), 126.6,128.8,129.1$ and 129.9 (arom.), $156.6(\mathrm{C}=\mathrm{N})$. Anal. Calcd. for $\mathrm{C}_{15} \mathrm{H}_{20} \mathrm{~N}_{2} \mathrm{O}_{2}(\mathrm{MW}=$ 260.33): C, 69.20; H, 7.74; N, 10.76. Found: C, 69.28; H, 7.79; $\mathrm{N}, 10.70$.

11Bc. (65\%), brown oil. IR: $\nu_{\max } 3060,1615 \mathrm{~cm}^{-1} \cdot R_{f}$ (chloroform/methanol 9:1) 0.24. ${ }^{1} \mathrm{H}-\mathrm{NMR}\left(300 \mathrm{MHz}, \mathrm{CDCl}_{3}\right)$ : $\delta_{\mathrm{H}} 1.19\left(3 \mathrm{H}, \mathrm{t}, J 7 \mathrm{~Hz}, \mathrm{CH}_{3}\right) ; 1.63(1 \mathrm{H}, \mathrm{d}, \mathrm{HC}-\mathrm{H}) ; 2.15(1 \mathrm{H}$, m, H-CH); $2.59\left(1 \mathrm{H}, \mathrm{d}, J 6 \mathrm{~Hz}, \mathrm{CH}-\mathrm{CH}_{2}-\mathrm{OH}\right) ; 2.74(2 \mathrm{H}, \mathrm{q}$, $\left.J 7 \mathrm{~Hz}, \mathrm{CH}_{2}\right) ; 3.47(1 \mathrm{H}, \mathrm{d}, J 3 \mathrm{~Hz}, \mathrm{CH}-\mathrm{N}) ; 3.59$ and $3.76(2 \mathrm{H}$, $\mathrm{AB}$ syst., $\left.\mathrm{CH}_{2}-\mathrm{OH}\right) ; 3.54\left(1 \mathrm{H}, \mathrm{d}, J 9 \mathrm{~Hz}, \mathrm{H} 4_{\text {isox }}\right) ; 4.90(1 \mathrm{H}$, d, J $\left.9 \mathrm{~Hz}, \mathrm{H} 5_{\text {isox }}\right) ; 7.42$ (3H, m, arom.); 7.70 (2H, m, arom.). ${ }^{13} \mathrm{C}-\mathrm{NMR}\left(75 \mathrm{MHz}, \mathrm{CDCl}_{3}\right) \delta_{\mathrm{C}} 14.8\left(\mathrm{CH}_{3}\right), 35.2\left(\mathrm{CH}_{2}\right), 41.3$ $(\mathrm{CH}), 46.7(\mathrm{CH}-\mathrm{NH}), 53.8\left(\mathrm{CH}_{2}-\mathrm{NH}\right), 64.6\left(\mathrm{CH}_{2}-\mathrm{OH}\right)$, $64.9(\mathrm{CH}-\mathrm{C}=\mathrm{N}), 91.9(\mathrm{CH}-\mathrm{O}), 126.6,126.8,128.8$ and 129.9 (arom.), $159.3(\mathrm{C}=\mathrm{N})$. Anal. Calcd. for $\mathrm{C}_{15} \mathrm{H}_{20} \mathrm{~N}_{2} \mathrm{O}_{2}(\mathrm{MW}=$ 260.33): C, 69.20; H, 7.74; N, 10.76. Found: C, 69.29; H, 7.79; $\mathrm{N}, 10.70$.

11Ad. (64\%), yellowish oil. IR: $v_{\max } 3294,1654 \mathrm{~cm}^{-1}$. $R_{f}$ (chloroform/methanol 9:1) $0.30 .{ }^{1} \mathrm{H}-\mathrm{NMR}(300 \mathrm{MHz}$, $\left.\mathrm{CDCl}_{3}\right): \delta_{\mathrm{H}} 1.14\left(6 \mathrm{H}, \mathrm{d}, J 6 \mathrm{~Hz}, \mathrm{CH}_{3}\right) ; 1.62(1 \mathrm{H}, \mathrm{m}, \mathrm{H}-$ $\mathrm{CH}) ; 2.23$ (1H, m, HC-H); $2.74(1 \mathrm{H}, \mathrm{m}, \mathrm{CH}) ; 2.93(1 \mathrm{H}, \mathrm{m}$, $\left.\mathrm{Me}_{2}-\mathrm{CH}\right) ; 3.47$ (1H, m, CH-N); 3.62 and 3.82 (2H, AB syst., $\left.\mathrm{CH}_{2}-\mathrm{OH}\right) ; 3.85(1 \mathrm{H}, \mathrm{d}, J 9 \mathrm{~Hz}, \mathrm{H} 4$ isox $) ; 5.28(1 \mathrm{H}, \mathrm{d}, J 9 \mathrm{~Hz}$, $\left.\mathrm{H} 5_{\text {isox }}\right) ; 7.44$ (3H, m, arom.); 7.68 (2H, m, arom.). ${ }^{13} \mathrm{C}-\mathrm{NMR}$ $\left(75 \mathrm{MHz}, \mathrm{CDCl}_{3}\right) \delta_{\mathrm{C}} 22.1\left(\mathrm{CH}_{3}\right), 23.2\left(\mathrm{CH}_{3}\right), 35.4\left(\mathrm{CH}_{2}\right)$, $45.8(\mathrm{CH}), 49.4(\mathrm{CH}-\mathrm{NH}), 59.4(\mathrm{CH}-\mathrm{NH}), 60.4\left(\mathrm{CH}_{2}-\mathrm{OH}\right)$, $64.0(\mathrm{CH}-\mathrm{C}=\mathrm{N}), 90.8(\mathrm{CH}-\mathrm{O}), 126.6,126.7,128.8$ and 129.9 (arom.), $156.7(\mathrm{C}=\mathrm{N})$. Anal. Calcd. for $\mathrm{C}_{16} \mathrm{H}_{22} \mathrm{~N}_{2} \mathrm{O}_{2}(\mathrm{MW}=$ 274.36): C, 70.04; H, 8.08; N, 10.21. Found: C, 70.00; H, 8.10; $\mathrm{N}, 10.31$.

11Bd. (53\%), yellow oil. IR: $\nu_{\max } 3360,1668 \mathrm{~cm}^{-1}$. $R_{f}$ (chloroform/methanol 9:1) $0.27 .{ }^{1} \mathrm{H}-\mathrm{NMR}(300 \mathrm{MHz}$, $\left.\mathrm{CDCl}_{3}\right): \delta_{\mathrm{H}} 1.16\left(6 \mathrm{H}, \mathrm{d}, J 6 \mathrm{~Hz}, \mathrm{CH}_{3}\right) ; 1.60(1 \mathrm{H}, \mathrm{m}, \mathrm{H}-$ $\mathrm{CH}) ; 2.18$ (1H, m, HC-H); $2.56(1 \mathrm{H}, \mathrm{m}, \mathrm{CH}) ; 2.97(1 \mathrm{H}, \mathrm{m}$, $\left.\mathrm{Me}_{2}-\mathrm{CH}\right) ; 3.59$ (1H, m, CH-N); 3.58 and 3.81 (2H, AB syst., $\left.\mathrm{CH}_{2}-\mathrm{OH}\right) ; 4.22\left(1 \mathrm{H}, \mathrm{d}, J 9 \mathrm{~Hz}, \mathrm{H} 4_{\text {isox }}\right) ; 4.89(1 \mathrm{H}, \mathrm{d}, J 9 \mathrm{~Hz}$, $\left.\mathrm{H} 5_{\text {isox }}\right) ; 7.42$ (3H, m, arom.); 7.70 (2H, m, arom.). ${ }^{13} \mathrm{C}-\mathrm{NMR}$ $\left(75 \mathrm{MHz}, \mathrm{CDCl}_{3}\right) \delta_{\mathrm{C}} 22.1\left(\mathrm{CH}_{3}\right), 23.0\left(\mathrm{CH}_{3}\right), 35.4\left(\mathrm{CH}_{2}\right)$, $45.6(\mathrm{CH}), 46.8(\mathrm{CH}-\mathrm{NH}), 53.8(\mathrm{CH}-\mathrm{NH}), 61.4\left(\mathrm{CH}_{2}-\mathrm{OH}\right)$, $64.8(\mathrm{CH}-\mathrm{C}=\mathrm{N}), 92.1(\mathrm{CH}-\mathrm{O}), 126.6,126.7,128.8$ and 129.9 (arom.), $159.4(\mathrm{C}=\mathrm{N})$. Anal. Calcd. for $\mathrm{C}_{16} \mathrm{H}_{22} \mathrm{~N}_{2} \mathrm{O}_{2}(\mathrm{MW}=$ 274.36): C, 70.04; H, 8.08; N, 10.21. Found: C, 70.09; H, 8.11; $\mathrm{N}, 10.11$.
11Ae. (68\%), brown oil. IR: $\nu_{\max } 3300,1558 \mathrm{~cm}^{-1} \cdot R_{f}$ (chloroform/methanol 9:1) 0.28. ${ }^{1} \mathrm{H}-\mathrm{NMR}\left(300 \mathrm{MHz}, \mathrm{CDCl}_{3}\right)$ : $\delta_{\mathrm{H}} 1.19(9 \mathrm{H}, \mathrm{s}, \mathrm{tBu}) ; 1.76(1 \mathrm{H}, \mathrm{d}, J 14 \mathrm{~Hz}, \mathrm{H}-\mathrm{CH}) ; 2.17(1 \mathrm{H}$, $\mathrm{m}, \mathrm{HC}-\mathrm{H}) ; 2.68(1 \mathrm{H}, \mathrm{d}, J 4 \mathrm{~Hz}, \mathrm{CH}) ; 3.52(1 \mathrm{H}, \mathrm{d}, J 6 \mathrm{~Hz}$, CH-N); 3.66 (2H, dd, J 11, $\left.3 \mathrm{~Hz}, \mathrm{CH}_{2}-\mathrm{OH}\right) ; 4.00(1 \mathrm{H}, \mathrm{d}, J$ $\left.9 \mathrm{~Hz}, \mathrm{H} 4_{\text {isox }}\right) ; 4.38(2 \mathrm{H}, \mathrm{b}, \mathrm{OH}$ and $\mathrm{NH}) ; 5.25(1 \mathrm{H}, \mathrm{d}, J 9 \mathrm{~Hz}$, $\left.\mathrm{H} 5_{\text {isox }}\right) ; 7.43$ (3H, m, arom.); 8.70 (2H, m, arom.). ${ }^{13} \mathrm{C}-\mathrm{NMR}$ $\left(75 \mathrm{MHz}, \mathrm{CDCl}_{3}\right) \delta_{\mathrm{C}} 29.2\left(\mathrm{CH}_{3}\right), 37.2\left(\mathrm{CH}_{2}\right), 49.9(\mathrm{CH})$, $52.2(\mathrm{CH}-\mathrm{NH}), 57.2(\mathrm{C}-\mathrm{NH}), 62.1\left(\mathrm{CH}_{2}-\mathrm{OH}\right), 63.7(\mathrm{CH}-$ $\mathrm{C}=\mathrm{N}), 90.4$ (CH-O), 125.8, 126.8, 128.0 and 129.4 (arom.), $156.3(\mathrm{C}=\mathrm{N})$. Anal. Calcd. for $\mathrm{C}_{17} \mathrm{H}_{24} \mathrm{~N}_{2} \mathrm{O}_{2}(\mathrm{MW}=288.38)$ : C, 70.80; H, 8.39; N, 9.71. Found: C, 70.88; H, 8.39; N, 9.70.

11Be. (66\%), light brown oil. IR: $\nu_{\max } 3300,1579 \mathrm{~cm}^{-1}$. $R_{f}$ (chloroform/methanol 9:1) $0.26 .{ }^{1} \mathrm{H}-\mathrm{NMR}(300 \mathrm{MHz}$, $\left.\mathrm{CDCl}_{3}\right): \delta_{\mathrm{H}} 1.25(9 \mathrm{H}, \mathrm{s}, \mathrm{tBu}) ; 1.68(1 \mathrm{H}, \mathrm{d}, J 14 \mathrm{~Hz}, \mathrm{H}-\mathrm{CH})$; $2.25(1 \mathrm{H}, \mathrm{m}, \mathrm{HC}-\mathrm{H}) ; 2.51(1 \mathrm{H}, \mathrm{d}, J 8 \mathrm{~Hz}, \mathrm{CH}) ; 3.25(2 \mathrm{H}, \mathrm{b}$, $\mathrm{OH}$ and $\mathrm{NH}) ; 3.67(1 \mathrm{H}, \mathrm{d}, J 6 \mathrm{~Hz}, \mathrm{CH}-\mathrm{N}) ; 3.64$ and $3.78(2 \mathrm{H}$, AB syst., $J$ 11, $\left.3 \mathrm{~Hz}, \mathrm{CH}_{2}-\mathrm{OH}\right) ; 4.17\left(1 \mathrm{H}, \mathrm{d}, J 9 \mathrm{~Hz}, \mathrm{H} 4_{\text {isox }}\right)$; $4.85\left(1 \mathrm{H}, \mathrm{d}, J 9 \mathrm{~Hz}, \mathrm{H} 5_{\text {isox }}\right) ; 7.43(3 \mathrm{H}, \mathrm{m}$, arom.); $7.71(2 \mathrm{H}$, m, arom.). ${ }^{13} \mathrm{C}-\mathrm{NMR}\left(75 \mathrm{MHz}, \mathrm{CDCl}_{3}\right) \delta_{\mathrm{C}} 29.6\left(\mathrm{CH}_{3}\right), 38.0$ $\left(\mathrm{CH}_{2}\right), 47.0(\mathrm{CH}), 51.9(\mathrm{CH}-\mathrm{NH}), 53.8(\mathrm{C}-\mathrm{NH}), 59.1\left(\mathrm{CH}_{2}-\right.$ $\mathrm{OH}), 64.8(\mathrm{CH}-\mathrm{C}=\mathrm{N}), 94.5(\mathrm{CH}-\mathrm{O}), 125.7,126.8,127.5$, 128.5, 128.8 and 129.9 (arom.), $159.7(\mathrm{C}=\mathrm{N})$. Anal. Calcd. for $\mathrm{C}_{17} \mathrm{H}_{24} \mathrm{~N}_{2} \mathrm{O}_{2}(\mathrm{MW}=288.38)$ : C, 70.80; $\mathrm{H}, 8.39 ; \mathrm{N}, 9.71$. Found: C, 70.79; H, 8.42; N, 9.74.

\section{Acknowledgments}

Financial support by the University of Pavia, MIUR (PRIN 2008, CUP: F11J10000010001) and EUTICALS S.p.a.-V.le Milano, 86/88-26900 Lodi, Italy is gratefully acknowledged. The authors wish to thank the Fondazione Banca del Monte di Lombardia for a research grant.

\section{References}

[1] B. Olofsson and P. Somfai, "Determination of the relativeconfiguration of vic-amino alcohols," Tetrahedron Letters, vol. 44, no. 6, pp. 1279-1281, 2003.

[2] S. Kobayashi, H. Ishitani, and M. Ueno, "Catalytic asymmetric synthesis of both syn- and anti- $\beta$-amino alcohols," Journal of the American Chemical Society, vol. 120, no. 2, pp. 431-432, 1998.

[3] D. J. Ager, I. Prakash, and D. R. Schaad, "1,2-amino alcohols and their heterocyclic derivatives as chiral aux-iliaries in asymmetric synthesis," Chemical Reviews, vol. 96, no. 2, pp. 835-876, 1996.

[4] A. Berkessel and R. Riedl, "Fluorescence reporters for phosphodiesterase activity," Angewandte Chemie, vol. 36, no. 13-14, pp. 1481-1483, 1997.

[5] G. Desimoni, G. Faita, and P. Quadrelli, "Pyridine-2,6bis(oxazolines), helpful ligands for asymmetric catalysts," Chemical Reviews, vol. 103, no. 8, pp. 3119-3154, 2003.

[6] G. Desimoni, G. Faita, and K. A. Jorgensen, " $\mathrm{C}_{2}$-symmetric chiral bis(oxazoline) ligands in asymmetric catalysis," Chemical Reviews, vol. 106, no. 9, pp. 3561-3651, 2006.

[7] B. S. Bodnar and M. J. Miller, "The nitrosocarbonyl heteroDiels-Alder reaction as a useful tool for organic syntheses," Angewandte Chemie, vol. 50, no. 25, pp. 5630-5647, 2011. 
[8] P. F. Vogt and M. J. Miller, "Development and applications of amino acid-derived chiral acylnitroso hetero Diels-Alder reactions," Tetrahedron, vol. 54, no. 8, pp. 1317-1348, 1998.

[9] L. Boger and S. M. Weinreb, Hetero Diels-Alder Methodology in Organic Synthesis, Academic Press, San Diego, Calif, USA, 1987.

[10] P. Quadrelli, M. Mella, P. Paganoni, and P. Caramella, "Cycloadditions of nitrile oxides to the highly reactive N-acyl-2oxa-3- azanorborn-5-enes afford versatile cycloadducts and a convenient entry to highly functionalized derivatives," European Journal of Organic Chemistry, no. 14, pp. 2613-2620, 2000.

[11] P. Quadrelli, V. Fassardi, A. Cardarelli, and P. Caramella, "Intra- and intermolecular hydrogen bonding effects in cycloadditions between nitrile oxides and 4-benzoylamino2-cyclopenten-1-ol and its derivatives," European Journal of Organic Chemistry, no. 13, pp. 2058-2065, 2002.

[12] P. Quadrelli, A. G. Invernizzi, and P. Caramella, "A mild oxidation of nitrile oxides: a new synthetic route to nitroso carbonyl intermediates," Tetrahedron Letters, vol. 37, no. 11, pp. 1909-1912, 1996.

[13] P. Quadrelli, M. Mella, A. G. Invernizzi, and P. Caramella, "The mild oxidation of nitrile oxides affords a convenient entry to nitrosocarbonyl intermediates, versatile tools in organic syntheses," Tetrahedron, vol. 55, no. 34, pp. 10497-10510, 1999.

[14] P. Quadrelli, A. Piccanello, N. V. Martinez, B. Bovio, M. Mella, and P. Caramella, "Isoxazoline-carbocyclic aminols for nucleoside synthesis through aza-Diels-Alder reactions," Tetrahedron, vol. 62, no. 31, pp. 7370-7379, 2006.

[15] P. A. Grieco and S. D. Larsen, "Iminium ion-based Diels -alder reactions: $N$-benzyl-2-azanorbornene [2-Azabicyclo[2.2.1] hept-5-ene, 2-(phenylmethyl)-]," Organic Syntheses, vol. 68, p. 206, 1990 .

[16] X. Sauvage and L. Delaude, "The synthesis of N-benzyl-2azanorbornene via aqueous hetero Diels-Alder reaction. An undergraduate project in organic synthesis and structural analysis," Journal of Chemical Education, vol. 85, no. 11, pp. 1538-1540, 2008.

[17] P. A. Grieco and A. Bahsas, "Immonium ion based synthetic methodology: a novel method for the $N$-methylation of dipeptides and amino acid derivatives via retro aza Diels-Alder reactions," Journal of Organic Chemistry, vol. 52, no. 26, pp. 5746-5749, 1987.

[18] S. D. Larsen and P. A. Grieco, "Aza Diels-Alder reactions in aqueous solution: cyclocondensation of dienes with simple iminium salts generated under Mannich conditions," Journal of the American Chemical Society, vol. 107, no. 6, pp. 17681769, 1985.

[19] J. E. Rodriguez-Borges, X. Garcia-Mera, F. Fernandez, V. H. C. Lopez, A. L. Magolhaes, and M. N. D. S. Cordeiro, "Expermintal AND dft study of the aza-diels-alder reaction between cyclopentadiene AND protoned benzylimine derivated from glyoxylates," Tetrahedron, vol. 61, no. 46, pp. 10951-10957, 2005.

[20] D. G. Lynn, K. Jaffe, M. Cornwall, and W. Tramontano, "Characterization of an endogenous factor controlling the cell cycle of complex tissues," Journal of the American Chemical Society, vol. 109, no. 19, pp. 5858-5859, 1987.

[21] P. A. Grieco, S. D. Larsen, and W. F. Fobare, "Aza Diels-Alder reactions in water: cyclocondensation of $\mathrm{C}$-acyl iminium ions with cyclopentadiene," Tetrahedron Letters, vol. 27, no. 18, pp. 1975-1978, 1986.
[22] D. A. Alonso, S. K. Bertilsson, S. Y. Johnsson, S. J.M. Nordin, M. J. Södergren, and P. G. Andersson, "New expedient route to both enantiomers of nonproteinogenic $\alpha$-amino acid derivatives from the unsaturated 2-aza-bicyclo moiety," Journal of Organic Chemistry, vol. 64, no. 7, pp. 2276-2280, 1999.

[23] P. D. Bailey, R. D. Wilson, and G. R. Brown, "Stereoselective synthesis of pipecolic acid derivatives using a aza-Diels-Alder reactions," Tetrahedron Letters, vol. 30, no. 48, pp. 6781-6784, 1989.

[24] H. Waldman, "Reactivity of tri-tert-butylazete," Angewandte Chemie International Edition in English, vol. 27, no. 2, pp. 272274, 1988.

[25] H. Abraham and L. Stella, "Reaction d'aza-diels-alder diastereoselective: utilisation de la 1-phenylethyl imine de glyoxylated d'alkyle pour la synthese de derives d' $\alpha$-amino acides cycliques," Tetrahedron, vol. 48, no. 44, pp. 9707-9718, 1992.

[26] L. Stella and H. Abraham, "Asymmetric Aza-Diels-Alder reaction using the chiral 1-phenyl-ethyl imine of methyl glyoxylate," Tetrahedron Letters, vol. 31, p. 2603, 1990.

[27] H. Böhme, K. Hartke, and A. Müller, "Über $\alpha$-halogenierte amine, XII. $\alpha$-halogenierte amine als dienophile verbindungen," Chemische Berichte, vol. 96, no. 2, pp. 607-608, 1963.

[28] D. S. Grierson and H. P. Husson, "Heteroatom manipulation," in Comprehensive Organic Synthesis, B. M. Trost and I. Fleming, Eds., vol. 6, pp. 909-947, Pergamon Press, Oxford, UK, 1991.

[29] R. Michelot, "Etude du mecanisme de le reaction de Polonovski, influence de la structure de l'oxyde d'amine sur le deroulement de la reaction," Bulletin de la Société Chimique de France, p. 4377, 1969.

[30] P. Quadrelli, B. Bovio, A. Piccinini, P. Caramella, F. de Sarlo, and F. Machetti, "Conversion of a nitrosocarbonyl hetero Diels-Alder cycloadduct to useful isoxazoline-carbocyclic aminols," Tetrahedron, vol. 65, no. 51, pp. 10679-10684, 2009.

[31] P. Quadrelli, A. Piccanello, M. Mella, A. Corsaro, and V. Pistarà, "From cyclopentadiene to isoxazoline-carbocyclic nucleosides: a rapid access to biological molecules through aza-Diels-Alder reactions," Tetrahedron, vol. 64, no. 16, pp. 3541-3547, 2008.

[32] C. Djerassi and R. R. Engle, "Oxidations with ruthenium tetroxide," Journal of the American Chemical Society, vol. 75, no. 15 , pp. 3838-3840, 1953.

[33] B. Plietker, "Selectivity versus reactivity-recent advances in $\mathrm{RuO}_{4}$ catalyzed oxidations," Synthesis, no. 15, Article ID E13405SS, pp. 2453-2472, 2005.

[34] H. Petride, O. Costan, C. Draghici, C. Florea, and A. Petride, " $\mathrm{RuO}_{4}$-Mediated oxidation of $\mathrm{N}$-benzylated tertiary amines. 2. Regioselectivity for N,N-dimethyl- and N,Ndiethylbenzylamine as substrates," Arkivoc, vol. 2005, no. 10, pp. 18-32, 2005.

[35] H. Petride, C. Draghici, C. Florea, and A. Petride, " $\mathrm{RuO}_{4}$ mediated oxidation of $N$-benzylated tertiary amines. Are amine $N$-oxides and iminium cations reactions intermediates?" Central European Journal of Chemistry, vol. 2, no. 2, pp. 302-322, 2004.

[36] M. G. Memeo, B. Bovio, and P. Quadrelli, " $\mathrm{RuO}_{4}$-catalyzed oxidation reactions of isoxazolino-2-azanorbornane derivatives: a short-cut synthesis of tricyclic lactams and peptidomimetic $\gamma$-amino acids," Tetrahedron, vol. 67, no. 10, pp. 1907-1914, 2011.

[37] P. Caramella and P. Grünanger, "Nitrile oxides and imines," in 1,3-Dipolar Cycloaddition Chemistry, A. Padwa, Ed., vol. 1, pp. 291-392, Wiley, New York, NY, USA, 1984. 
[38] A. Piperno, U. Chiacchio, D. Iannazzo, S. V. Giofrè, G. Romeo, and R. Romeo, "First example of direct $\mathrm{RuO}_{4}$-catalyzed oxidation of isoxazolidines to 3-isoxazolidones," Journal of Organic Chemistry, vol. 72, no. 10, pp. 3958-3960, 2007.

[39] P. H. J. Carlsen, T. Katsuki, V. S. Martin, and K. B. Sharpless, "A greatly improved procedure for ruthenium tetroxide catalyzed oxidations of organic compounds," Journal of Organic Chemistry, vol. 46, no. 19, pp. 3936-3938, 1981.

[40] M. Kaname and S. Yoshifuji, "First synthesis of lycoperdic acid," Tetrahedron Letters, vol. 33, no. 52, pp. 8103-8104, 1992.

[41] S. Yoshifuji and M. Kaname, "Asymmetric synthesis of lycoperdic acid," Chemical and Pharmaceutical Bulletin, vol. 43, no. 10, pp. 1617-1620, 1995.

[42] P. Merino, J. Revuelta, T. Tejero et al., "Enantioselective synthesis of 4-hydroxy-D-pyroglutamic acid derivatives by an asymmetric 1,3-dipolar cycloaddition," Tetrahedron Asymmetry, vol. 13, no. 2, pp. 167-172, 2002.

[43] S. M. Daluge, M. T. Martin, B. R. Sickles, and D. A. Livingston, "An efficient, scalable synthesis of the HIV reverse transcriptase inhibitor Ziagen@ (1592U89),” Nucleosides, Nucleotides and Nucleic Acids, vol. 19, no. 1-2, pp. 297-327, 2000.

[44] N. M. Yoon, C. S. Pak, H. C. Brown, S. Krishnamurthy, and T. P. Stocky, "Selective reductions. XIX. Rapid reaction of carboxylic acids with borane-tetrahydrofuran. Remarkably convenient procedure for the selective conversion of carboxylic acids to the corresponding alcohols in the presence of other functional groups," Journal of Organic Chemistry, vol. 38, no. 16 , pp. 2786-2792, 1973.

[45] J. V. B. Kanth and M. Periasamy, "Selective reduction of carboxylic acids into alcohols using $\mathrm{NaBH}_{4}$ and $\mathrm{I}_{2}$," Journal of Organic Chemistry, vol. 56, no. 20, pp. 5964-5965, 1991.

[46] P. Grünanger and P. V. Finzi, Isoxazoles, John Wiley \& Sons, New York, NY, USA, 1991.

[47] R. Huisgen, P. H. J. Ooms, M. Mingin, and N. L. Allinger, "Exceptional reactivity of the bicyclo[2.2.1] heptene double bond," Journal of the American Chemical Society, vol. 102, no. 11, pp. 3951-3953, 1980.

[48] N. G. Rondan, M. N. Paddon-Row, P. Caramella, and K. N. Houk, "Nonplanar alkenes and carbonyls: a molecular distortion which parallels addition stereoselectivity," Journal of the American Chemical Society, vol. 103, no. 9, pp. 2436-2438, 1981.

[49] P. Caramella, N. G. Rondan, M. N. Paddon-Row, and K. N. Houk, "Origin of $\pi$-facial stereoselectivity in additions to $\pi$ bonds: generality of the anti-periplanar effect," Journal of the American Chemical Society, vol. 103, no. 9, pp. 2438-2440, 1981.

[50] K. N. Houk, N. G. Rondan, F. K. Brown, W. L. Jorgensen, J. D. Madura, and D. C. Spellmeyer, "The origin and consequences of alkene pyramidalization in ground and triplet excited states," Journal of the American Chemical Society, vol. 105, no. 19, pp. 5980-5988, 1983.

[51] M. G. Memeo, D. Mantione, B. Bovio, and P. Quadrelli, " $\mathrm{RuO}_{4}$-catalyzed oxidation reactions of $N$-alkylisoxazolino-2azanorbornane derivatives: an expeditious route to tricyclic $\gamma$ lactams," Synthesis, no. 13, pp. 2165-2174, 2011.

[52] J. M. Bakke and A. E. Frøhaug, "Ruthenium tetraoxide mediated reactions: the mechanisms of oxidations of hydrocarbons and ethers," Journal of Physical Organic Chemistry, vol. 9, no. 6, pp. 310-318, 1996.

[53] J. M. Bakke and A. E. Frøhaug, "Mechanism of $\mathrm{RuO}_{4}-\mathrm{me}-$ diated oxidations of saturated hydrocarbons, isotope effects, solvent effects and substituent effects," Journal of Physical Organic Chemistry, vol. 9, no. 7, pp. 507-513, 1996.
[54] J. M. Bakke and J. E. Braenden, "Derivatisation of saturated hydrocarbons. The mechanism $\mathrm{RuO}_{4}$ Oxidation," Acta Chemica Scandinavica, vol. 45, no. 4, pp. 418-423, 1991.

[55] T. Naota, H. Takaya, and S. L. Murahashi, "Ruthenium-catalyzed reactions for organic synthesis," Chemical Reviews, vol. 98, no. 7, pp. 2599-2660, 1998.

[56] A. E. Shilov and G. B. Shul'pin, "Activation of C-H bonds by metal complexes," Chemical Reviews, vol. 97, no. 8, pp. 28792932, 1997.

[57] G. Lin, K. K. Midha, and E. M. Hawes, "Synthesis of the piperidinone metabolites of piperidine type phenothiazine antipsychotic drugs via ruthenium tetroxide oxidation," Journal of Heterocyclic Chemistry, vol. 28, no. 2, pp. 215-219, 1991.

[58] J. Zabicky, The Chemistry of Amides, John Wiley \& Sons, London, UK, 1970.

[59] N. G. Gaylord, Reduction with Complex Metal Hydrides, Intersceince Publishers, New York, NY, USA, 1956.

[60] J. R. Malpass and N. J. Tweddle, "Reaction of chlorosulphonyl isocyanate with 1,3-dienes. Control of 1,2-and 1,4-addition pathways and the synthesis of aza- and oxa-bicyclic systems," Journal of the Chemical Society, Perkin Transactions, no. 8, pp. 874-883, 1977. 


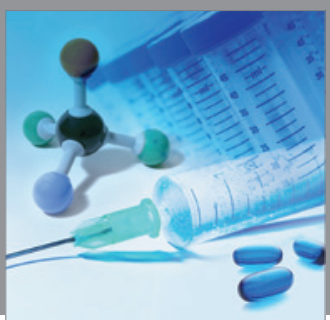

International Journal of

Medicinal Chemistry

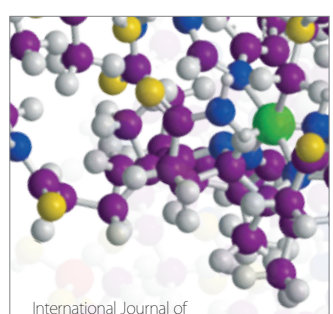

Carbohydrate Chemistry

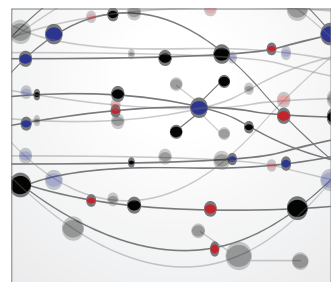

The Scientific World Journal
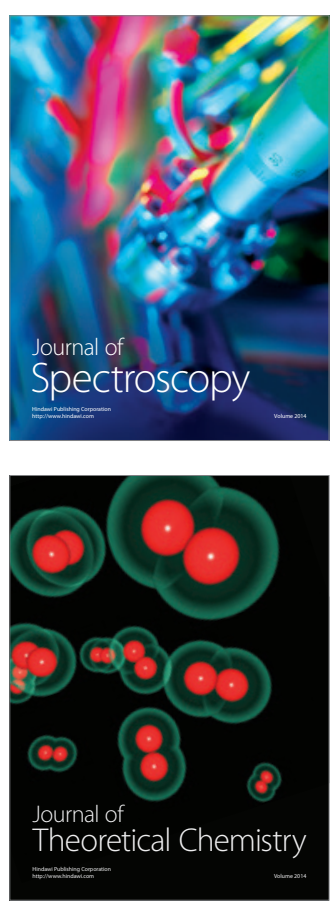
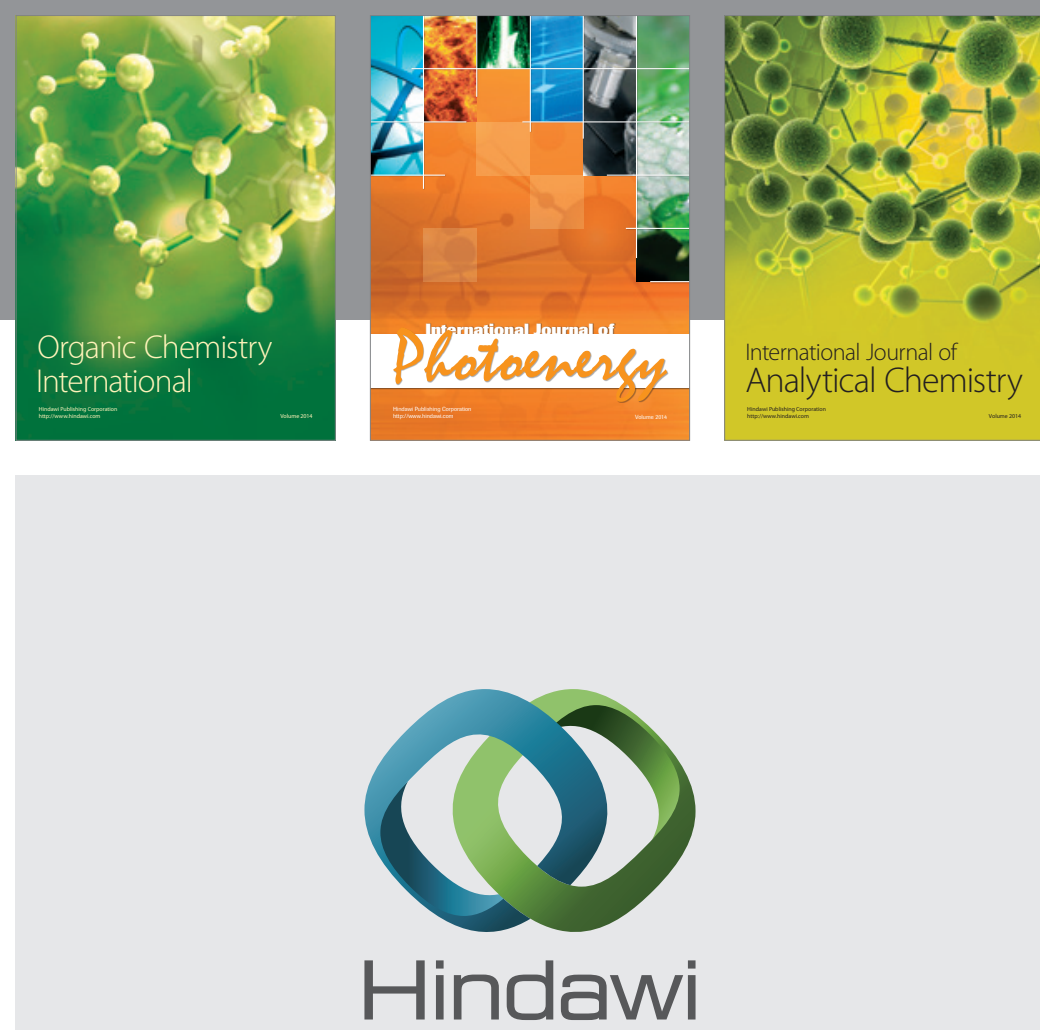

Submit your manuscripts at

http://www.hindawi.com
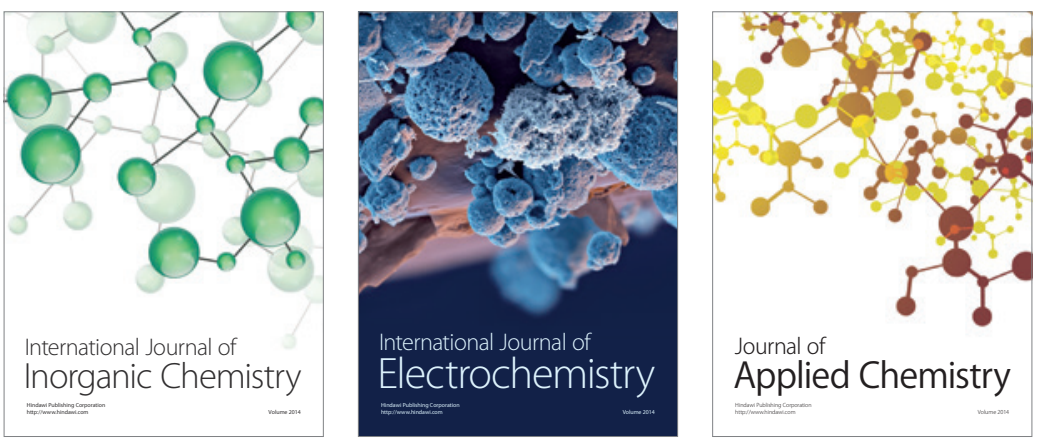

Journal of

Applied Chemistry
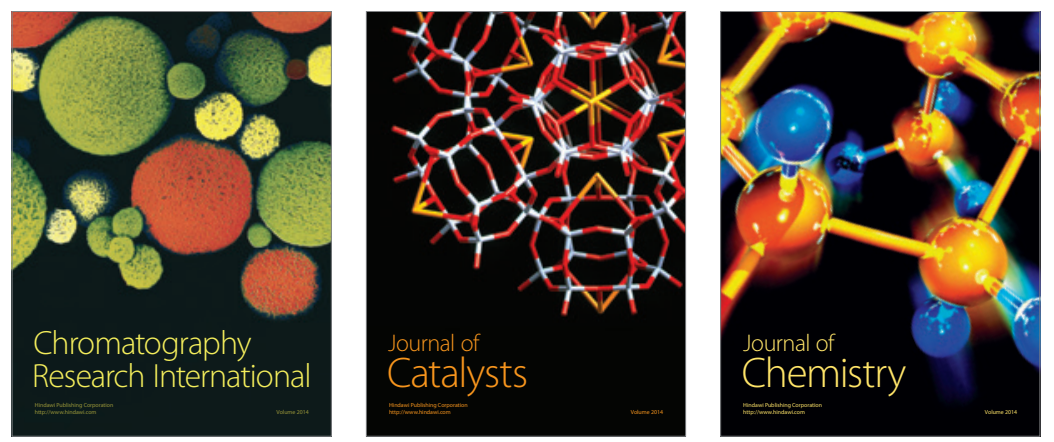
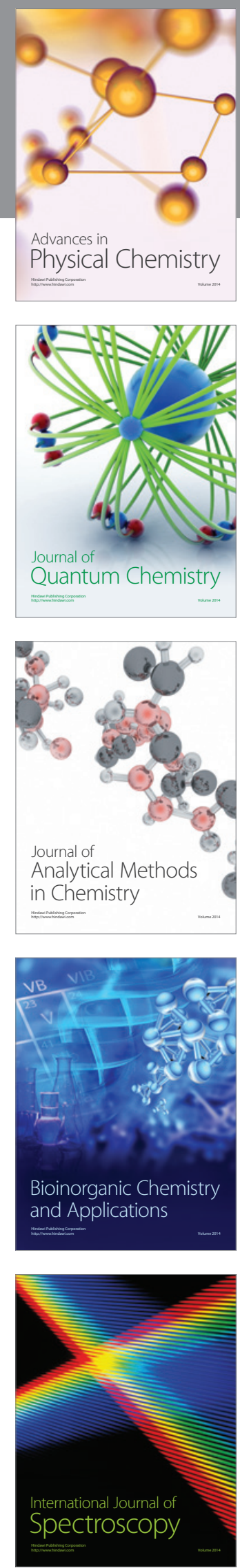